\title{
The Effect of Using "SMARICALITION" Poster on Students' Writng Skill at SMA N 2 Tanjung Pinang
}

\author{
Rona Elfiza ${ }^{1}$, Ratna $^{1}$ \\ ${ }^{1}$ Universitas Maritim Raja Ali Haji \\ email: ronaelfiza@umrah.ac.id \\ email: ratnaharvardiastar86@gmail.com
}

\begin{abstract}
Writing an analytical exposition text is one of skills that should be mastered by students in Senior High School. Teaching medium has important role to facilitate the students in writing analytical exposition text. SMARICALITION (Smart Analytical Exposition) Poster is one of media can be used in teaching writing analytical exposition text. This article retrieved from the research on the effect of using SMARICALITION Poster on students' writing skill of SMAN 2 Tanjungpinang. This research was conducted as a quasi-experimental research. The purpose of the study is to test whether SMARICALITION Poster give significant effect on students'writing skill or not. The population of this research was the 11th grade students of SMAN 2 Tanjungpinang. There were five classes of social major and seven classes of science major. The sample of this study was XI Science 3 and XI science 4. XI Science 3 was the experimental group, whereas XI Science 4 was the control group. There were 38 students investigated in each class. The sample was taken by using multistage cluster sampling. This study used written test as its instrument. The result of this research was students' writing skill who were taught by using SMARICALITION Poster was better than students' speaking skill who weren't taught by SMARICALITION Poster. It can be concluded that SMARICALITION Poster gave significant effect toward students' writing skill at SMAN 2 Tanjungpinang.
\end{abstract}

Keywords: Effect, SMARICALITION” Poster, writing skill

\begin{abstract}
Abstrak
Menulis teks eksposisi analitis merupakan salah satu keterampilan yang harus dimiliki oleh siswa di Sekolah Menengah Atas. Media pembelajaran memiliki peranan penting dalam memfasilitasi siswa dalam menulis teks eksposisi analitis. Poster SMARICALITION (poster pintar eksposisi analitis) adalah salah satu media yang biasa digunakan dalam pengajaran menulis teks eksposisi analitis. Artikel ini ditulis berdasarkan penelitian tentang pengaruh penggunaan Poster SMARICALITION terhadap keterampilan menulis SMAN 2 Tanjungpinang. Penelitian ini merupakan penelitian kuasi eksperimen. Tujuan dari penelitian ini adalah untuk menguji apakah poster SMARICALITION memberikan efek yang signifikan terhadap keterampilan menulis siswa atau tidak. Populasi dari penelitian ini adalah siswa kelas XI SMAN 2 Tanjungpinang. Kelas XI terdiri dari 5 kelas IPS dan 7 kelas IPA. Sampel dari penelitian ini menggunakan kelas XI IPA 3 dan XI IPA 4. Kelas XI IPA merupakan kelas eksperimen sementara kelas control adalah kelas IPA 4. Masing masing kelas terdiri dari 38 siswa. Instrument dari penelitian ini adalah tes menulis. Hasil dari
\end{abstract}


penelitian ini menunjukan bahwa siswa yang diajar dengan menggunakan poster SMARICALITION memiliki keterampilan menulis lebih baik daripada siswa yang diajarkan dengan tidak menggunakan poster SMARICALITION. Maka dapat disimpulkan bahwa poster SMARICALITION memberikan efek yang signifikan terhadap keterampilan menulis siwa di SMA N 2 Tanjungpinang.

Kata Kunci: Pengaruh, Poster SMARICALITION”,Keterampilan menulis

\section{INTRODUCTION}

Writing is one of the most important skills that should be mastered to communicate in written form. This skill helps everyone to deliver his/her idea. By having a good ability in writing, everyone can explore and organize his/her ideas cohesively and coherently into a written communication. Writing is a process form letters and words, and to join these together to make words, sentences or a series of sentences that link together to communicate a message, (Spratt, Pulverness, \& Williams, 2005). More than that, writing can also improve someone's ability in thinking analytically and critically. Therefore, everyone should have a good writing skill to have a good written communication.

Weigle (2002) states that a good writing has criteria as follow (1) Addresses effectively the writing task,(2) Is organized and developed well,(3)Uses clearly suitable details to support a thesis or illustrate ideas,(4) Shows consistent using of language, and (5) Demonstrates syntactic variety and appropriate diction though it may have occasional errors. However, writing skill is not easy. Many students regard that writing is very difficult to be mastered. Writing needs a long process. In this process, writer goes through some stages in order to produce something in its final written form. This process may be affected by the content of the writing, the types of writing, and the media it is written in (Harmer, 2004).

Writing needs an extra energy and enough knowledge. To make writing easier, students have to have a good skill in organizing their ideas. More than that, they should have a high motivation in doing it. Because of that, a new strategy is needed to help the students in writing. Furthermore, students must be able to afford themselves to have a good writing skill.

The ability to communicate well in written communication is one of the expected abilities of senior high school students, (Kemendikbud, 2013). Senior high school students must be able to produce a good writing. This writing can help them to have a good written communication. In short, they have to be able to master writing based on what they have to achieve in senior high school level.

In senior high school, genre based approach is used in teaching writing. One of the text genres which have to be learnt by the students is analytical exposition text. Writing an analytical exposition text can help students to have a good analytical thinking in taking a look at an issue. Indeed, analytical exposition text is very important to be written by the students.

Talking about writing an analytical exposition text, there are two factors which can influence the students' skill in writing analytical exposition text. The first is internal factors, and the second is external factors. Internal factors consist of learning 
style, personality, interest, language element, etc. Then the external factors consist of teachers' competence, school facilities, and media in learning process.

Learning medium is one of supporting aspects to facilitate the students in writing analytical exposition text. Using learning media in teaching- learning process can increase a new talent and desire, increase the motivation and the stimulation of learning activity, and even bring psychological influences on the students (Falahudin, 2014). Learning media can help students to have many ideas by stimulating their thinking and feeling. More than that, by stimulating the students' interest, learning media can also increase their motivation. Of course, both idea and motivation can support the students to produce a good analytical exposition text.

Therefore, learning media are very important in helping students to have a good skill in writing analytical exposition texts. Since learning media are very important to help students to have a good skill in writing analytical exposition text, the teachers should be able to provide appropriate learning media. However, based on the researcher's observation, sometimes teachers got confused in choosing the appropriate learning media for teaching writing. They need a new reference which can help them to find new media in teaching writing. One of media can be used by teacher is poster.

Poster is one of the graphic media that can be used by teachers to stimulate their students to find ideas for writing analytical exposition text. Poster is a combination of a drawing and a short article in one image field which has esthetic values in order to attract the people who see it (Rahmaniati, 2015). This medium can ease and increase students' understanding on the material discussed and it can be served with colors which can attract students' attention (Riadi, 2015). SMARICALITION (Smart Analytical Exposition) poster is a kind of informative poster. This poster informs and educates students about something. The researcher designs this poster to give students extra knowledge about certain topic. (Example of SMARICALITION at appendix 1).

There have been some researchers conducted by researchers which related to the use of poster. The first related research had already been conducted by Zerin and Khan (2013) the result of this research showed that poster presentation could develop language proficiency and provide room for innovation and creativity that promote active language learning. Furthermore Aduradola and Bolanle I (2013) found that poster could enhance oral communication skills' development of the students in the area of listening, speaking, reading, and writing.

The third related research had already been conducted by Şener and Bostan (2017) the result of the research showed that posters had an important effect on the results of vocabulary test and they facilitate self-directed L2 vocabulary. Based on the issues above, the researcher became interested in conducting research to know the effect of using SMARICALITION Poster on students' writing skill at $11^{\text {th }}$ grade of SMA Negeri 2 Tanjungpinang. By knowing the effect of using SMARICALITION Poster on students' writing skill, it can be considered whether the SMARICALITION Poster can be used as one of learning media in teaching writing.

\section{METHOD}

This research was conducted as a quasiexperimental research. In this research, the researcher used "post-test-only design." In 
this type of quasi experiment, the experimental group gets the treatment and post-test; whereas the control group only gets post-test without any treatments (Creswell, 2012).The population of this research was the student at 11th grade of SMA Negeri 2 Tanjungpinang. There were five classes of social major and seven classes of science major. The sample of this research was XI Science 4 as control class and XI Science 3 as experimental class.

The sampling technique which was used in this research was multistage cluster sampling. Multistage cluster sampling is a kind of probability sampling in which the researcher chooses the sample in two or more stages because the researcher cannot identify the population easily (Creswell, 2012).

Written test was instrument of this research. The test constructed on the Holistic Scoring Rubric. Weigle, S. C. (2002) explains that there are six aspect of writing rubric. They are (1) Suitability between the content and the title, (2) the systematical of the text, (3) the accuracy of the information, (4) the language consistency, (5) the syntactic accuracy, and (6) the word choice. The rubric of this writing test can be seen in appendix 2 .

In order to find the effect of using SMARICALITION Poster on students' writing skill in analytical exposition text, the researcher checked the normality and the homogeneity of the data first. To see the normality test of the Students' Writing Score, the researcher used Minitab 17. Then, to know whether the variance of the students' writing score was homogenous or not, the researcher conducted a homogeneity test by using Minitab 17. Since the variances were homogenous and the data were normally distributed, in testing hypothesis applied Two Sample T Test. The Two Sample T Test was also conducted by using Minitab 17.

\section{FINDING AND DISCUSSION}

In describing the data of students' writing skill in experimental class and control class, the researcher conducted some measurements of the data by using Minitab 17. The result of the measurements could be summarized in this following table.

Table 1. Summary of Students' Writing Skill Data

\begin{tabular}{|l|l|l|}
\hline & $\begin{array}{l}\text { Experimental } \\
\text { Class }\end{array}$ & Control Class \\
\hline Total Score & 3333 & 2800 \\
\hline $\begin{array}{l}\text { Minimum } \\
\text { Score }\end{array}$ & 76.00 & 60.00 \\
\hline $\begin{array}{l}\text { Maximum } \\
\text { Score }\end{array}$ & 95.00 & 84.00 \\
\hline Mean & 87.71 & 73.68 \\
\hline $\begin{array}{l}\text { Standard } \\
\text { Deviation }\end{array}$ & 5.08 & 6.41 \\
\hline Variance & 25.83 & 41.09 \\
\hline
\end{tabular}

Based on Table 1 above, it could be seen that the difference between the result of students' writing skill in experimental class and the result of students' writing skill in control class was significant. It could be proven by the mean which showed that the average score in experimental class was 87.71, and the average score in control class was 73.68 . It shows a significant difference between students' writing skill in experimental class and control class with the range 14.03. In analyzing the data, the researcher conducted normality and homogeneity test for students' writing score. The normality and homogeneity could be seen as follows:

1. Data Analysis of Students' Writing Score a. Normality Test of the Students' Writing Score in Experimental Class

To see the result of the normality test of the Students' Writing Score in Experimental Class, the researcher used Minitab 17. Based on the measurement 
which was conducted by using the program, the result could be seen as follows:

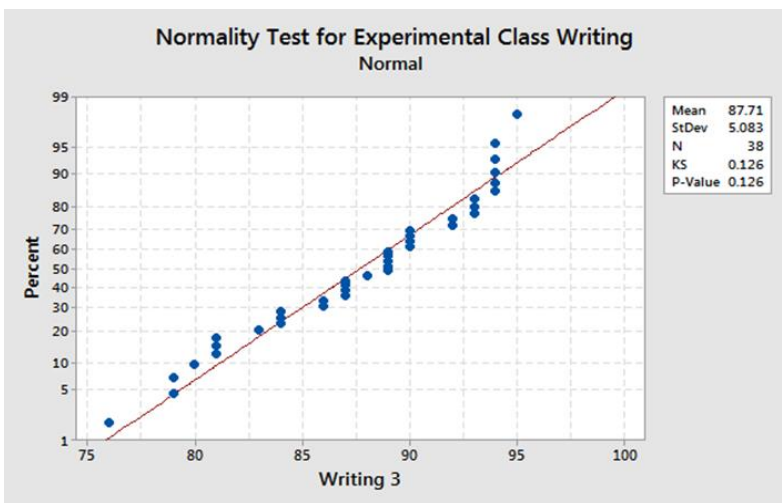

Figure 1 : Normality test in experimental class.

Based on the result above, it could be seen that the P-Value $=0.126$ which was bigger than the $\alpha=0.05$. It meant that the Ho was accepted, while the $\mathrm{Ha}$ was rejected. It proved that the students' writing score in experimental class was in normal distribution.

b. Normality Test of the Students' Writing Score in Control Class

To see the result of the normality test of control class writing score, the researcher also used Minitab 17. The result could be seen as follows

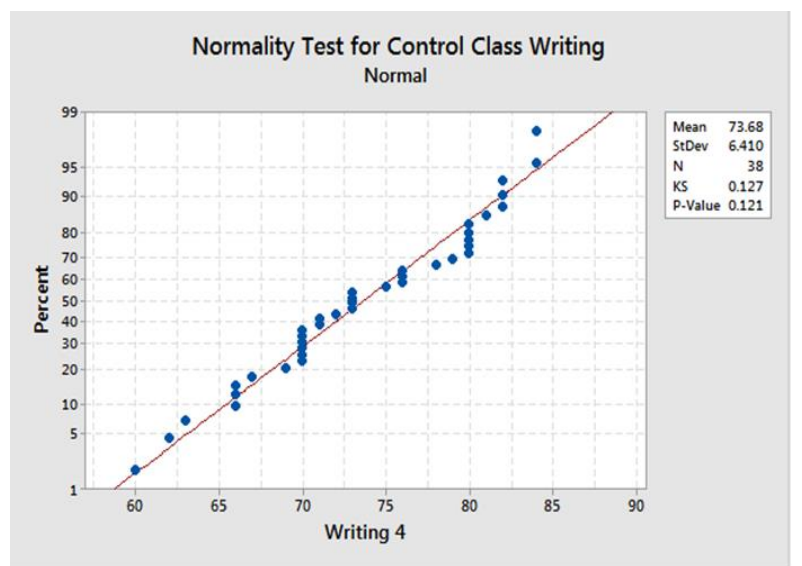

Figure 2: Normality test in control class
Based on the result above, the $\mathrm{P}$ Value $=0.121$ which was bigger than the $\alpha$ $=0.05$. Because of that, the Ho was accepted, while the $\mathrm{Ha}$ was rejected. Therefore, the result of the normality test above showed that the students' writing score in control class was in normal distribution. The result of the normality tests above could be summarized in this following table.

Table 2. Summary of Normality Test

\begin{tabular}{|l|l|l|l|}
\hline Class & \multicolumn{1}{|l|}{ P-Value } & A & Conclusion \\
\hline Experimental & 0.126 & 0.05 & Normal \\
\hline Control & 0.121 & 0.05 & Normal \\
\hline
\end{tabular}

\section{Homogeneity Test}

To know whether the variance of the students' writing score was homogenous or not, the researcher conducted a homogeneity test by using Minitab 17 . The result of the test could be seen as follow:

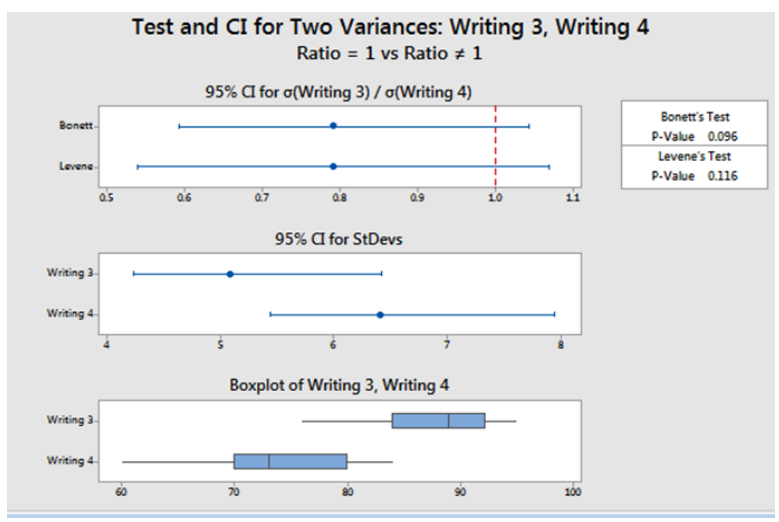

Figure 3: Homogeneity test

From the result above, it could be seen that in Bonett's test, the P-Value = 0.096, and in Levene's test, the P-Value = 0.116. Both of the P-Values showed that they were bigger that the $\alpha=0.05$ which meant that the Ho was accepted, while the Ha was rejected. In brief, the variance of the students' writing score was homogenous.

Based on the data analysis above, it could be concluded that the test of 
hypothesis for the data of students' writing score should be conducted by using Two Sample T Test. It was because of the data could fulfill all of the requirements of normality and homogeneity; the data were in normal distribution, and the variance of the data was homogenous.

\section{Test of Hypothesis}

Before testing the hypothesis, the researcher stated the alternative hypothesis and the null hypothesis for the students' writing skill. The alternative hypothesis (Ha) and the null hypothesis (Ho) are stated in these following statements:

$\mathrm{Ha}=$ There is a significant effect of using SMARICALITION Poster on students' writing skill in writing analytical exposition text.

$\mathrm{Ho}=$ There is no significant effect of using SMARICALITION Poster on students' writing skill in writing analytical exposition text.

In testing the hypothesis for students' writing skill, the researcher used Two Sample T Test. The result of the hypothesis testing which was conducted by using Minitab 17 can be seen as follow

Figure 4: Hypothesis test

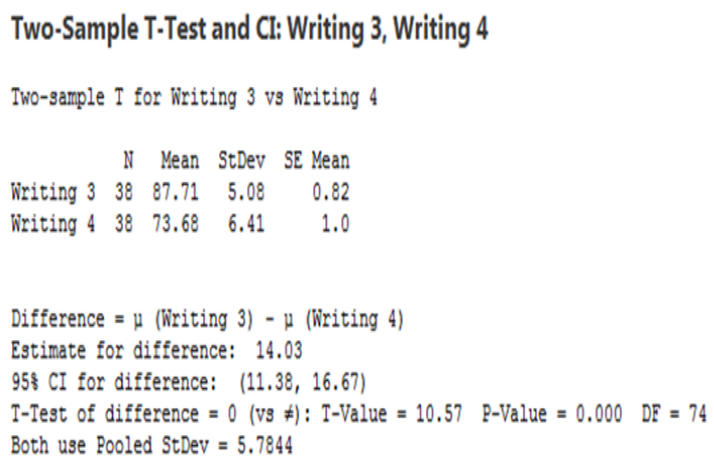

From the result above, it could be seen that the P-Value $=0.000$. This value was smaller than the $\alpha=0.025$. Because of that, the alternative hypothesis was accepted, while the null hypothesis was rejected. The result of the hypothesis testing above could be summarized in this following table.

Table 3 Summary of Hypothesis Testing

\begin{tabular}{|l|l|r|l|}
\hline Variable & P-Value & A & Conclusion \\
\hline $\begin{array}{l}\text { Writing } \\
\text { skill }\end{array}$ & 0.000 & 0.025 & Accept Ha \\
\hline
\end{tabular}

From the result above, it could be seen that the P-Value $=0.000$. This value was smaller than the $=0.025$. Because of that, the alternative hypothesis was accepted, while the null hypothesis was rejected. It meant that there was a significant effect of using SAMARICALITION Poster on students' writing skill in writing analytical exposition text.

Students' writing skill who was taught by using SMARICALITION Poster is better than those who were not taught by SMARICALITION poster. It could be explained by some reasons. First, SMARICALITION poster emphasizes the power of messages, visuals, and colors. It can be used by the teachers to stimulate their students to collect ideas for writing, especially for writing analytical exposition text. Hence, poster can be very helpful for students to help them to produce a good analytical exposition text. This poster was a colorful and structured poster which contained the explanation about analytical exposition text and the information which could be used to give stimulation to the students at 11th grade of SMA Negeri 2 Tanjungpinang in writing an analytical exposition text. In addition, this poster could also be profitable for students in collecting ideas for writing and helping them to produce a good analytical exposition text. Osa and Musser (2004) explain that posters motive and inspire students to learn, stimulate interest in the topic and effectively illustrate a concept or skill. 
Next, SMARICALITION Poster helps students to develop their language skills. Aduradola \& Akeredolu (2013) argue that Poster could enhance oral communication skills' development of the students in the area of listening, speaking, reading and writing. Then, SMARICALITION Poster facilitates students to enrich their vocabulary. Sener \& Bostan (2017) explain that posters had an important effect on the results of vocabulary tests and they facilitate selfdirected L2 vocabulary learning.

In brief, it can be concluded that the result of the analysis of the effect of using SMARICALITION Poster on students' writing skill in writing analytical exposition text in this research was clearly in accordance with related theories. Based on the discussion above, the students' writing skill in experimental class that used SMARICALITION Poster in writing the analytical exposition text was significantly different from the students' writing skill in control class that did not use the SMARICALITION Poster. It proved that there was a significant effect of using SMARICALITION Poster on students' writing skill. Therefore, it could be concluded that using SMARICALITION Poster could give a significant effect on students' writing skill at 11th grade of SMA Negeri 2 Tanjungpinang in writing analytical exposition text.

\section{CONCLUSION}

Based on the data analysis described above, the conclusion can be drawn that the using of SMARICALITION Poster can give a significant effect on students' writing skill at 11th grade of SMA Negeri 2 Tanjungpinang in writing analytical exposition text. This could be proven by the result of the Two Sample $\mathrm{T}$ Test which were conducted and analyzed by the researcher. The result of the analysis of students' writing skill showed that the PValue $=0.000$ was smaller than the $\alpha=$ 0.025 which meant that the alternative hypothesis which stated that the alternative hypothesis which stated that there is a significant effect of using SMARICALITION Poster on students' writing skill in analytical exposition text had to be accepted.

SMARICALITION Poster can give a significant effect on students' writing skill in SMAN 2 Tanjungpinang because of its strengths. First this poster was able to stimulate students to collect ideas for writing, especially for writing analytical exposition text. Hence, poster can be very helpful for students to help them to produce a good analytical exposition text. Since this poster was a colourful and structured poster which contained the explanation about analytical exposition text and the information.

Besides that, SMARICALITION POSTER also helps students in collecting ideas for writing and helping them to produce a good analytical exposition text. Then, this poster also enhances students' writing skill and enriches their vocabulary, because SMARICALITION poster gives students extra knowledge about certain topic. This poster is a combination of a drawing and a short article in one image field which has esthetical values.

\section{REFERENCES}

Aduradola, R. R., \& Akeredolu, B. I. (2013). The Power of Student's Involvement: Using Posters as Teaching Tools in Managing Large Classes. English for Specific Purposes World, 14(40), 1-20.

Creswell, J. W. (2012). Educational Research: Planning, Conducting and 
Evaluating Quantitative and Qualitative Research (Fourth). Boston: Pearson Education.

Falahudin, I. (2014). Pemanfaatan Media dalam Pembelajaran. Jurnal Lingkar Widyaiswara, 1(4), 104-117.

Harmer, J. (2004). How to Teach Writing. Edinburgh: Pearson Education Limited.

Rahmaniati, R. (2015). Penggunaan Media Poster untuk Meningkatkan Hasil

Belajar IPA Peserta Didik Kelas VB SDN 6 Langkah Palangka Raya. Pedagogik Jurnal Pendidikan, 10(2), 59-64.

Riadi, M. (2015). Media Pembelajaran Poster. Retrieved September 29, 2018, from

https://www.kajianpustaka.com/2015/0 3/media-pembelajaranposter.html? $\mathrm{m}=1$

Sener, S., \& Bostan, D. (2017). Using Posters in EFL Classroom: An Elementary School Case. International
Kemendikbud. (2013). Pengembangan Kurikulum 2013.Jakarta: Kemendikbud

Osa Justina O and Musser Linda R (2004) The Role of Posters in Teacher Education Programs Education Libraries Volume 27, No. 1 Summer

Online Journal of Education and Teaching, 4(4), 552-560

Spratt, M., Pulverness, A., \& Williams, M. (2005). The Teaching Knowledge Test Course. Cambridge: Cambridge University Press.

Weigle, S. C. (2002). Assessing Writing. Cambridge: Cambridge University Press.

Zerin, S., \& Khan, S. A. (2013). Poster - A Visual Stimulus for Active Learning. GSTF International Journal of Law and Social Sciences (JLSS), 3(1), 1-6. https://doi.org/10.5176/2251-2853 


\section{APPENDIX 1}

\section{SMARICALITION POSTER}
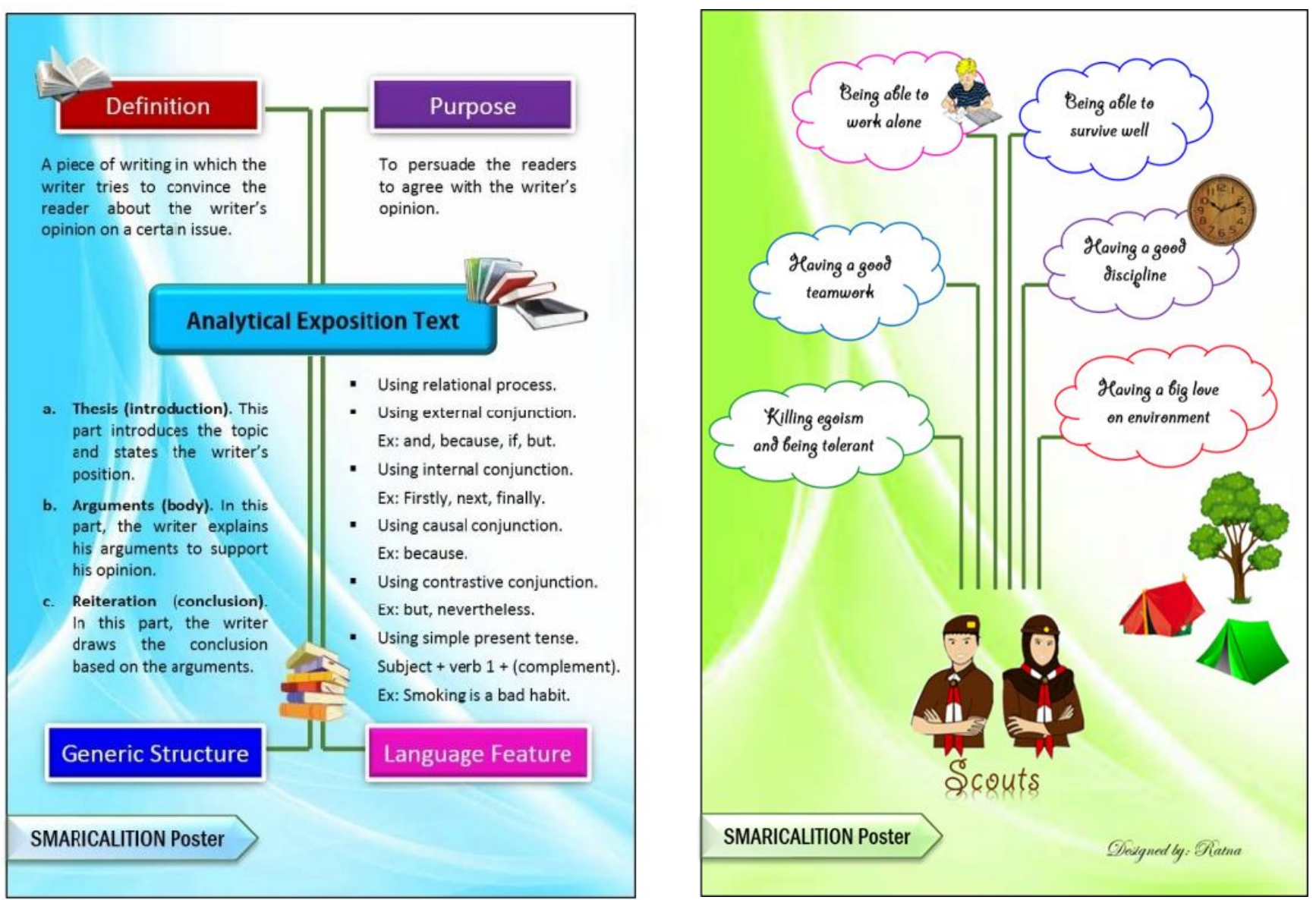
Appendix 2

\section{Rubric of Writing \\ (Scoring Guide)}

\begin{tabular}{|c|c|c|c|}
\hline $\begin{array}{l}\mathrm{Nu} \\
\mathrm{mbe} \\
\mathrm{r}\end{array}$ & Aspect & Criteria & Score \\
\hline 1 & $\begin{array}{l}\text { Suitability } \\
\text { between the } \\
\text { content and the } \\
\text { title }\end{array}$ & $\begin{array}{l}\text { - The content is very suitable with the title } \\
\text { - } \quad \text { The content is suitable with the title } \\
\text { - } \quad \text { The content is suitable enough with the title. } \\
\text { - } \quad \text { The content is less suitable with the title. } \\
\text { - } \quad \text { The content is not suitable with the title }\end{array}$ & $\begin{array}{ll}- & 17-20 \\
- & 13-16 \\
- & 9-12 \\
- & 5-8 \\
- & 0-4\end{array}$ \\
\hline 2 & $\begin{array}{l}\text { The } \\
\text { systematical } \\
\text { of the text }\end{array}$ & $\begin{array}{l}\text { - } \begin{array}{l}\text { The systematical of the text is very appropriate } \\
\text { - }\end{array} \text { The systematical of the text is appropriate. } \\
\text { - } \quad \text { The systematical of the text is appropriate enough } \\
\text { - } \quad \text { The systematical of the text is less appropriate } \\
\text { - } \quad \text { The systematical of the text is not appropriate }\end{array}$ & $\begin{array}{ll}- & 13-15 \\
- & 10-12 \\
- & 7-9 \\
- & 4-6 \\
- & 0-3\end{array}$ \\
\hline 3 & $\begin{array}{l}\text { The accuracy of } \\
\text { the information }\end{array}$ & $\begin{array}{l}\text { - The accuracy of the information is very is clear } \\
\text { - } \quad \text { The accuracy of the information is clear enough. } \\
\text { - } \quad \text { The accuracy of the information is less clear } \\
\text { - } \quad \text { The accuracy of the information is not clear } \\
\text { - } \quad \text { The language consistency is very appropriate }\end{array}$ & $\begin{array}{ll}- & 13-15 \\
- & 10-12 \\
- & 7-9 \\
- & 4-6 \\
- & 0-3\end{array}$ \\
\hline 4 & $\begin{array}{l}\text { The language } \\
\text { Consistency }\end{array}$ & $\begin{array}{ll}\text { - } & \text { The language consistency is very appropriate } \\
\text { - } & \text { The language consistency is appropriate. } \\
\text { - } & \text { The language consistency is appropriate enough. } \\
\text { - } & \text { The language consistency is less appropriate } \\
\text { - } & \text { The language consistency is not appropriate }\end{array}$ & $\begin{array}{ll}- & 17-20 \\
- & 13-16 \\
- & 9-12 \\
- & 5-8 \\
- & 0-4\end{array}$ \\
\hline 5 & $\begin{array}{l}\text { The syntactic } \\
\text { Accuracy }\end{array}$ & $\begin{array}{l}\text { - } \quad \text { The syntactic accuracy is very appropriate. } \\
\text { - } \quad \text { The syntactic accuracy is appropriate. } \\
\text { - } \quad \text { The syntactic accuracy is appropriate enough. } \\
\text { - } \quad \text { The syntactic accuracy is less appropriate. } \\
\text { - } \quad \text { The syntactic accuracy is not appropriate. }\end{array}$ & $\begin{array}{ll}- & 13-15 \\
- & 10-12 \\
- & 7-9 \\
- & 4-6 \\
- & 0-3\end{array}$ \\
\hline 6 & The word choice & $\begin{array}{l}\text { - } \quad \text { The word choice is very suitable. } \\
\text { - } \quad \text { The word choice is suitable. } \\
\text { - } \quad \text { The word choice is suitable enough } \\
\text { - } \quad \text { The word choice is less suitable. } \\
\text { - } \quad \text { The word choice is not suitable. }\end{array}$ & $\begin{array}{ll}- & 13-15 \\
- & 10-12 \\
- & 7-9 \\
- & 4-6 \\
- & 0-3\end{array}$ \\
\hline
\end{tabular}

Constructed based on the Holistic Scoring Rubric.

Source: Weigle, S. C. (2002). Assessing Writing. Cambridge: Cambridge University Press. 